\title{
Cytokine-dependent invasiveness in B16 murine melanoma cells: Role of uPA system and MMP-9
}

\author{
FRANCESCA BIANCHINI, SILVIA D'ALESSIO, GABRIELLA FIBBI, MARIO DEL ROSSO and LIDO CALORINI
}

Department of Experimental Pathology and Oncology, University of Florence, Florence, Italy

Received August 5, 2005; Accepted September 26, 2005

\begin{abstract}
Proteases are crucial for the spread of cancer cells from a primary tumor to the site of secondary growth. This study examined the ability of IFN $\gamma$ and TNF $\alpha$ to stimulate a better invasiveness in B16 murine melanoma cells, and investigated whether this enhanced ability was related to a higher expression of protease activities, such as urokinase plasminogen activator (uPA) and its receptor (uPAR), and matrix metalloproteinases 2 and 9 (MMP-2, MMP-9). We found that murine melanoma cells enhanced their lungcolonizing potential in vivo and invasiveness through Matrigel-coated filters upon costimulation with IFN $\gamma$ and $\mathrm{TNF} \alpha$; neither IFN $\gamma$ nor TNF $\alpha$ alone, at the dose used in the experiments, was able to elicit a change in the invasive/ metastatic efficiency of melanoma cells. The invasive phenotype of murine melanoma cells stimulated with IFN $\gamma$ and TNF $\alpha$ was characterized by an enhanced uPA/uPAR and MMP-9 expression: TNF $\alpha$ promoted MMP-9 mRNA expression and pro-MMP-9 protein secretion, and the costimulation with IFN $\gamma$ and $\mathrm{TNF} \alpha$ was required to potentiate the expression of mRNA and protein for UPAR, and to induce a redistribution of $\mathrm{uPA}$ from the soluble to the cell bodyassociated form. Both monoclonal antibodies, anti-uPAR and anti-MMP-9, caused a significant reduction of invasiveness in IFN $\gamma / \mathrm{TNF} \alpha$-stimulated melanoma cells. These results indicate that invasiveness in B16 murine melanoma cells can be regulated in a cytokine-specific fashion and is dependent on the synergism between the UPA/uPAR system and MMP-9.
\end{abstract}

\section{Introduction}

Experimental evidence has led to the recognition that the expression in tumor cells of some biological activities typical of a metastatic phenotype is due to temporary genetic changes

Correspondence to: Dr Lido Calorini, Dipartimento di Patologia e Oncologia Sperimentali, Università degli Studi di Firenze, Viale G.B. Morgagni 50, 50134 Firenze, Italy

E-mail: lido.calorini@unifi.it

Key words: murine melanoma cells, lung metastasis, cell invasiveness, IFN $\gamma, \mathrm{TNF} \alpha$, matrix metalloproteinases, uPA/uPAR system caused by cellular and humoral host factors $(1,2)$. The tumor microenvironment contains many host cells, such as mast cells, fibroblasts, endothelial cells, macrophages, and lymphocytes. Among the various types of host cells, tumor-associated macrophages (TAMs) play a critical role in tumor progression. Whereas TAMs may destroy tumor cells following their activation $(3,4)$, they may also produce growth factors, cytokines and proteases that promote invasion and metastatic diffusion of tumor cells (5-13). It is of particular interest that the failure to recruit macrophages into the tumor microenvironment in colony stimulating factor-deficient ( $\mathrm{CSF}^{\circ} / \mathrm{CSF}^{\circ}$ ) mice reduced the metastatic spread of transplanted mammary cancer (14). Studies performed in our laboratory showed that macrophages, elicited by immune agents $(C$. parvum, BCG, $L$. monocytogenes), secreted in their growth medium a prometastatic activity which enhanced the ability of B16 murine melanoma cells to colonize the lung of syngeneic mice (10) and migrate through Matrigel (15). We demonstrated that this macrophage prometastatic activity had to be ascribed to the cooperative effect of two inflammatory cytokines, IFN $\gamma$ and $\mathrm{TNF} \alpha$. The capacity of exogenous IFN $\gamma$ to stimulate the formation of metastases in murine melanoma cells was related to the capacity of IFN $\gamma$ to induce a higher expression of MHC class I antigens (17-19), a change to escape NK activity $(17,18)$. IFN $\gamma$ may also promote metastatic diffusion of melanoma cells through a down regulation of the processing of tumor antigens (20-22). TNF $\alpha$ promoted the invasiveness of human melanoma cells through the stimulation of the expression of integrin receptors (23), or cell-bound degradative enzymes (24).

In this study, we explored whether the invasive/metastatic phenotype of B16 murine melanoma cells stimulated with exogenous IFN $\gamma$ and $\mathrm{TNF} \alpha$ was associated with a change in protease expression. Among the different proteases that might play a role in tumor dissemination, we focused our attention on matrix metalloproteinases 2 and 9 (MMP-2, MMP-9) and urokinase-type plasminogen activator (uPA) and its receptor (uPAR). Both systems of proteases are markers of melanoma progression. Indeed, uPA/uPAR and MMP are expressed in advanced stages of primary and metastatic melanoma lesions (25-27). Moreover, antisense oligonucleotide-driven inhibition of UPAR expression in human melanoma cells inhibited lung metastases in an experimental model of spontaneous metastasis in nude mice (28). Similar data are available for MMPs $(26,27)$, whose control by genetic (29) and pharmacological means (30) has 
Table I. Oligonucleotide primer pairs used in RT-PCR analysis.

\begin{tabular}{|c|c|c|c|c|c|c|}
\hline Gene product & Forward primer $\left(5^{\prime} \rightarrow 3^{\prime}\right)$ & Reverse primer $\left(5^{\prime} \rightarrow 3^{\prime}\right)$ & $\begin{array}{l}\text { Product } \\
\text { (bp) }\end{array}$ & $\begin{array}{c}\text { Annealing } \\
\text { temperature }\left({ }^{\circ} \mathrm{C}\right)\end{array}$ & Cycles & Author/Ref. \\
\hline $\mathrm{uPA}$ & TATGCAGCCCTATGGCTC & GAAGTGTGACCCTGTGTAGAC & 210 & 60 & 34 & Rakic, et al (41) \\
\hline uPAR & GGACTCCCAAGGCGGCTGCTGC & GGGCCACCATTGCAGTGGGTG & 598 & 55 & 34 & Gutierrez, et al (42) \\
\hline MMP-9 & GCTCCTGGCTCTCCTGGCTT & GTCCCACTTGAGGCCTTTGA & 331 & 55 & 30 & Itoh, et al (29) \\
\hline MMP-2 & AGAGACCTCAGGGTGACAC & AAGAAGTTGTAGTTGGCCA & 330 & 55 & 30 & Itoh, et al (29) \\
\hline$\beta_{2}$ Microglobulin & TGCTATCCAGAAAACCCCTC & GTCATGCTTAACTCTGCAGG & 258 & 55 & 30 & Orlic, et al (43) \\
\hline
\end{tabular}

been shown to inhibit the aggressiveness of experimental melanoma. However, information on the control of these proteases by inflammatory cytokines in tumor cells is still limited, and an inconsistency in the trend is seen in the present information (31-38).

\section{Materials and methods}

Cell lines and culture conditions. In this study, we used a low metastatic clone of B16-F10 murine melanoma cells, the F10-M3 cells (39). Cells were cultivated in Dulbecco's modified Eagle's medium (DMEM 4500, Gibco) supplemented with $10 \%$ fetal calf serum (Boehringer Mannheim, Germany), at $37^{\circ} \mathrm{C}$ in a $10 \% \mathrm{CO}_{2}$ humidified atmosphere. Cells were harvested from subconfluent cultures by incubation with a trypsin-EDTA solution, and propagated every three days. Cell viability was determined by trypan blue exclusion test. Cultures were periodically monitored for mycoplasma contamination using Chen's fluorochrome test (40).

Cytokine-treated murine melanoma cells were obtained by incubating tumor cells, for a period of $24 \mathrm{~h}$, in media supplemented with IFN $\gamma(25 \mathrm{U} / \mathrm{ml})$ and/or TNFa $25 \mathrm{ng} / \mathrm{ml})$ (Peprotech, England). Cytokine concentrations were chosen based on our previous experiments performed to investigate the prometastic activity of IFN $\gamma$ and TNF $\alpha$ (16).

Lung colonization. B16 melanoma cells were harvested from dishes by the use of trypsin-EDTA solution. Cells were washed twice in PBS and then suspended in serum-free medium at $25 \times 10^{5}$ cells $/ \mathrm{ml} .0 .2 \mathrm{ml}$ of this suspension was injected into the tail veins of syngeneic $\mathrm{C} 57 \mathrm{Bl} / 6$ mice. The animals were monitored and sacrificed 21 days later. The lungs were inspected using a dissecting microscope and lung nodules were counted.

In vitro invasion assay. Invasiveness of B16 melanoma cells was determined on Matrigel-coated polycarbonate filters $(8-\mu \mathrm{m}$ pore size) mounted in Boyden's chambers. The coated filters were prepared by using Matrigel suspensions at $250 \mu \mathrm{g} / \mathrm{ml}$. B16 melanoma cells $\left(25 \times 10^{3}\right)$ suspended in $200 \mu 1$ DMEM 4500 containing $250 \mu \mathrm{g} / \mathrm{ml} \mathrm{BSA}$ were seeded in the upper chamber and incubated for 18-24 h. After incubation, cells on the upper side of the filters were wiped off and the membranes were fixed overnight in ice-cold methanol. Cells on the lower side of the membranes were stained with Diff Quick and counted.
In some experiments, the migration ability of tumor cells was tested in the presence of monoclonal antibodies antiuPAR $(26 \mu \mathrm{g} / \mathrm{ml}$, final concentration) (R\&D Systems, USA), and monoclonal antibodies anti-MMP-9 (17.5 $\mu \mathrm{g} / \mathrm{ml}$, final concentration) (Chemicon, USA).

RNA isolation and polymerase chain reaction (PCR). Total RNA was extracted from cells using Trizol reagent (Gibco), and the amount and purity of the RNA was determined spectrophotometrically. cDNA was synthesized from $1 \mu \mathrm{g}$ of total RNA using $4 \mathrm{U} / \mu 1$ of M-MLV reverse transcriptase (Promega, Madison, WI). Aliquots of $5 \mu 1$ of the cDNA were used for PCR amplification. The murine UPA, uPAR, MMP-2, MMP-9, $\beta_{2}$-microglobulin were identified using the primers listed in Table I. All PCR reactions were conducted using $0.1 \mathrm{U} / \mu 1$ of Go-Taq polymerase (Promega). Amplification was carried out on a Perkin-Elmer thermal cycler. Ten $\mu 1$ of each PCR product were visualized after electrophoresis in a $2 \%$ agarose gel containing $0.5 \mathrm{mg} / \mathrm{ml}$ of ethidium bromide. cDNA products were evaluated on the basis of a standard PCR marker (Promega).

Western blotting analysis. B16 melanoma cells were washed twice with ice-cold PBS containing $1 \mathrm{mM} \mathrm{Na}_{4} \mathrm{VO}_{3}$. Cells were lysed in $100 \mu \mathrm{l}$ of cell lysis buffer containing $20 \mathrm{mM}$ Tris$\mathrm{HCl}$ (pH 7.4), $150 \mathrm{mM} \mathrm{NaCl}, 100 \mathrm{mM}$ Hepes, $1 \%$ Triton $\mathrm{X}-100,10 \mathrm{mM}$ glycerophosphate, $100 \mu \mathrm{M}$ PMSF, $100 \mathrm{mM}$ AEBSF, $5 \mathrm{mM}$ bestatin, $2 \mathrm{mM}$ leupeptin, $1 \mathrm{mM}$ pepstatin A, and $80 \mu \mathrm{M}$ of aprotinin, $1.5 \mathrm{mM}$ E-64. Supernatants containing equal amounts of protein $(65 \mu \mathrm{g})$ in Laemmli buffer were separated on $10 \%(\mathrm{v} / \mathrm{v})$ SDS-PAGE gel. Fractionated proteins were transferred from the gel to a PVDF nitrocellulose membrane. Blots were stained with Ponceau red to ensure equal loading and complete transfer of proteins and then blocked with $2.5 \%(\mathrm{w} / \mathrm{v})$ bovine serum albumin (BSA) in T-TBS $[0.1 \%(\mathrm{v} / \mathrm{v})$ Tween-20 in PBS] for $1 \mathrm{~h}$ at room temperature. Subsequently, the membrane was probed with uPAR (R\&D Systems) goat anti-mouse monoclonal antibody, 1:1000 diluted with $2.5 \%(\mathrm{w} / \mathrm{v})$ skimmed milk in T-PBS buffer at $4^{\circ} \mathrm{C}$ overnight. After washing in T-PBS buffer, the membrane was incubated with a horseradish peroxidaseconjugated rabbit anti-goat antibody (Santa Cruz, USA), 1:8000 dilution in $2.5 \%(\mathrm{w} / \mathrm{v}) \mathrm{BSA} / \mathrm{T}-\mathrm{PBS}$, for $1 \mathrm{~h}$. After successive washing with T-PBS, the immunoreactive bands were visualized using the ECL detection system (Amersham, Arlington Heights, IL, USA). 
Zymography for MMPs. Aliquots from media conditioned by tumor cells were electrophoresed on $8 \%$ SDS-polyacrylamide gels co-polymerized with $0.1 \%$ (w/v) type A gelatin (Sigma). After electrophoresis, the gels were washed in $2.5 \% \mathrm{v} / \mathrm{v}$ Triton X-100 (Sigma) for $30 \mathrm{~min}$ to remove SDS. Gelatin substrate gels were then incubated in $50 \mathrm{mM}$ Tris- $\mathrm{HCl}, \mathrm{pH} 7.4,200 \mathrm{mM}$ $\mathrm{NaCl}$ and $5 \mathrm{mM} \mathrm{CaCl}_{2}$ for $24 \mathrm{~h}$ at $37^{\circ} \mathrm{C}$. After incubation, the gels were stained with $0.1 \%$ Coomassie brilliant blue (Merck) in acetic acid, methanol and distilled water at a volume ratio of 1:2:3, respectively, for $60 \mathrm{~min}$ at room temperature. The gels were destained in the same solution without the Coomassie for $2 \mathrm{~h}$. After destaining, the gels were immersed in distilled water and scanned immediately. Gelatinolytic activity was demonstrated as clear bands on a blue background.

Analysis of uPA enzymatic activity. Culture medium and cell lysate aliquots were concentrated by centrifugation at $8000 \mathrm{rpm}$ for $30 \mathrm{~min}$ in centricon tubes (Amicon Division, Beverly, MA, USA) with $30-\mathrm{kDa}$ molecular weight cut-off pores. The samples were subjected to sodium dodecyl sulfate (SDS)polyacrylamide slab gel electrophoresis $(10 \%)$ under nonreducing conditions and migrated proteins were transferred onto a $0.45-\mu \mathrm{m}$ pore-size nitrocellulose filter (BioRad Laboratories, Richmond, California, USA) in a $40-\mathrm{mM}$ phosphate buffer ( $\mathrm{pH}$ 6.5), under a current of 0.4 A for a 2-h run. The nitrocellulose filter was removed and placed on an indicating layer containing casein and plasminogen. After overnight incubation at $37^{\circ} \mathrm{C}$, when clear bands of lysis were visible in the cloudy casein background, corresponding to the position of plasminogen activators in the polyacrylamide gel, zymograms were dried and stained with Ponceau S solution (Sigma). uPA activity was measured by densitometric scanning of the zymograms, against standard uPA.

Statistical analysis. The statistical significance of the differences between unstimulated tumor cells and cytokinestimulated tumor cells was determined using the Student's t-test. Invasion assays were performed in triplicate in at least two to three different experiments. Data are expressed as means \pm SEM.

\section{Results}

Fig. 1A shows that the combined treatment of B16 murine melanoma cells with IFN $\gamma$ and $\mathrm{TNF} \alpha$ promoted a better capacity to colonize lungs of syngeneic animals, an effect which neither IFN $\gamma$ nor $\mathrm{TNF} \alpha$ alone, as reported in a previous paper by our laboratory (16), was able to elicit. B16 murine melanoma cells stimulated with IFN $\gamma$ and TNF $\alpha$ also showed a greater invasiveness through Matrigel-coated filters (Fig. 1B).

RT-PCR analysis and zymography revealed that melanoma cells, grown in standard conditions, do not express MMP-2 and MMP-9, a behaviour which also characterized melanoma cells treated with IFN $\gamma$ (Fig. 2). At the variance with this behaviour, TNF $\alpha$ and the combination of IFN $\gamma$ and TNF $\alpha$, stimulated MMP-9 mRNA expression in melanoma cells (Fig. 2A). Zymography of media conditioned by stimulated tumor cells revealed that TNF $\alpha$ and the combination of IFN $\gamma$ and $\mathrm{TNF} \alpha$ stimulated pro-MMP-9 release (Fig. 2B). As shown in Fig. 3, IFN $\gamma$ and TNF $\alpha$ promoted the expression of uPAR
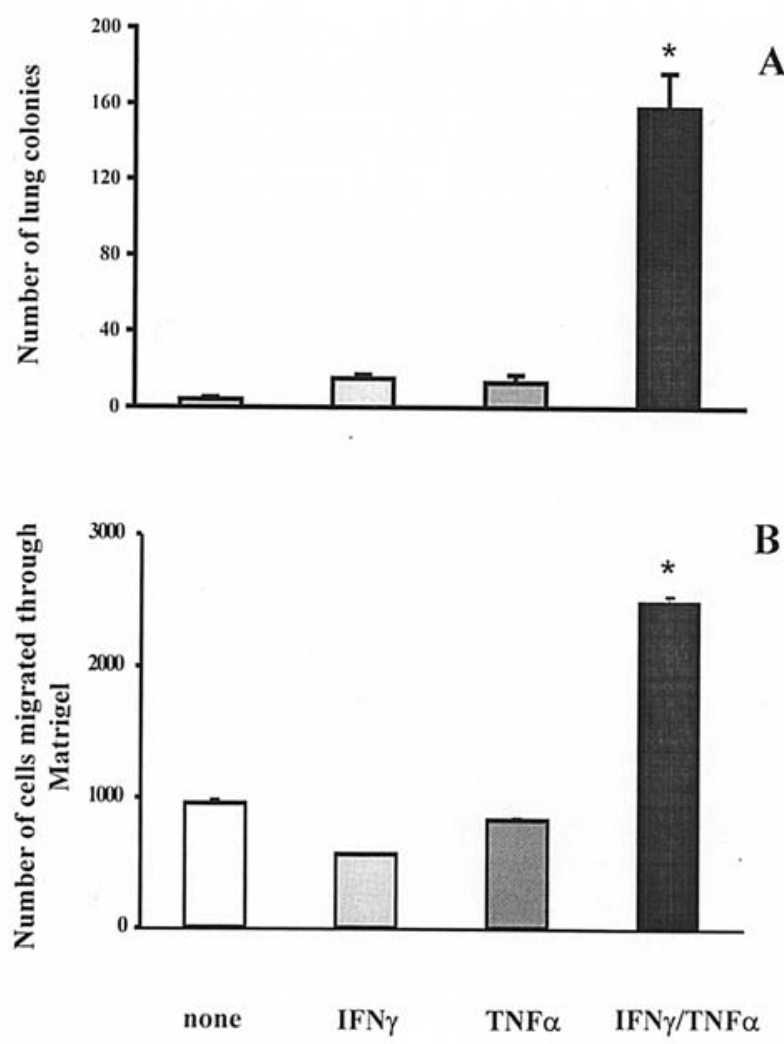

Figure 1. Change in lung colonization (A) and invasiveness through Matrigel (B) in F10-M3 murine melanoma cells stimulated with IFN $\gamma$ and/or TNF $\alpha$. *Significantly different at $\mathrm{p}<0.001$.

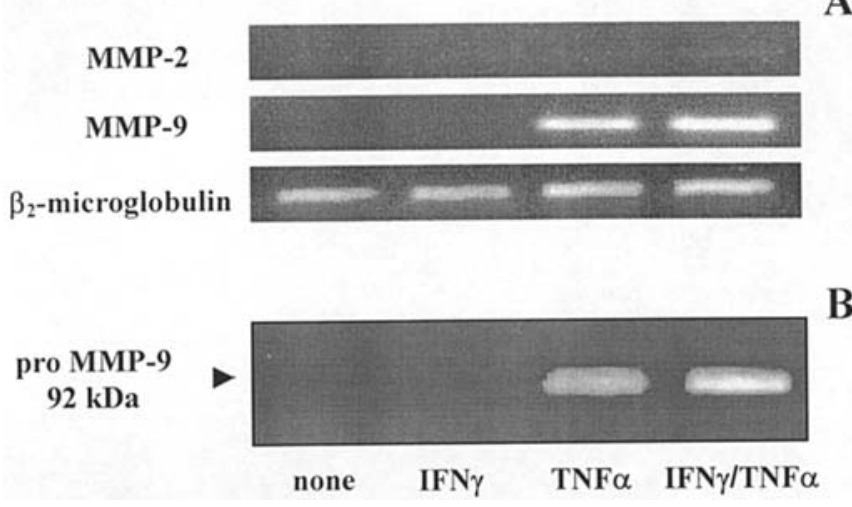

Figure 2. Change in MMP-9 in F10-M3 murine melanoma cells stimulated with IFN $\gamma$ and/or TNF $\alpha$. RT-PCR analysis of total RNA for MMP-2 and MMP-9 (A), and gelatin zymogram of conditioned media (B) of tumor cells grown in the presence and absence of cytokines.

mRNA (panel A) and protein (panel B) in tumor cells. IFN $\gamma$ alone induced a slight increase of mRNA for uPAR (panel A) that was not associated with a change in protein synthesis (panel B). The level of mRNA for uPA was found to remain unchanged in tumor cells stimulated with IFN $\gamma$ and/or TNF $\alpha$ (panel A) but, as revealed by casein zymography of media conditioned by tumor cells costimulated with IFN $\gamma$ and TNF $\alpha$ performed in parallel with casein zymography of cell bodies of the same tumor cells, uPA redistributed from the soluble to the cell body-associated compartment (panel C). 
A

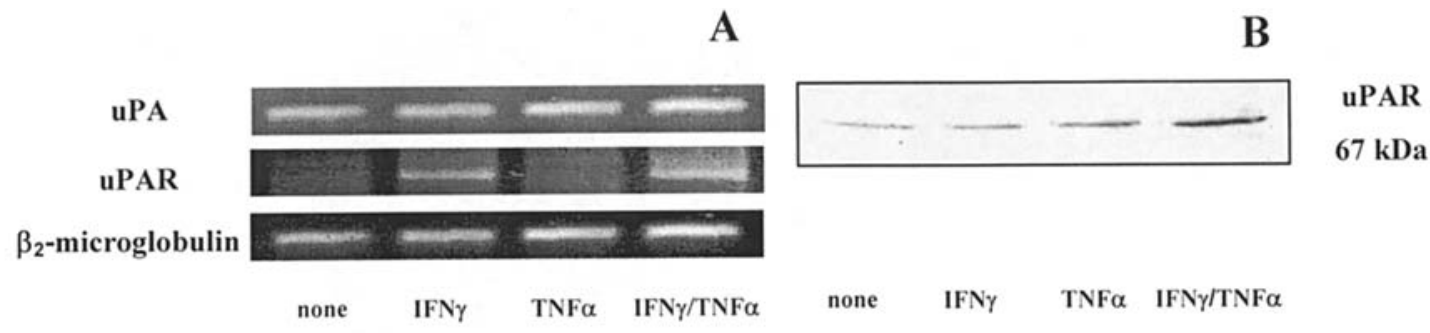

C

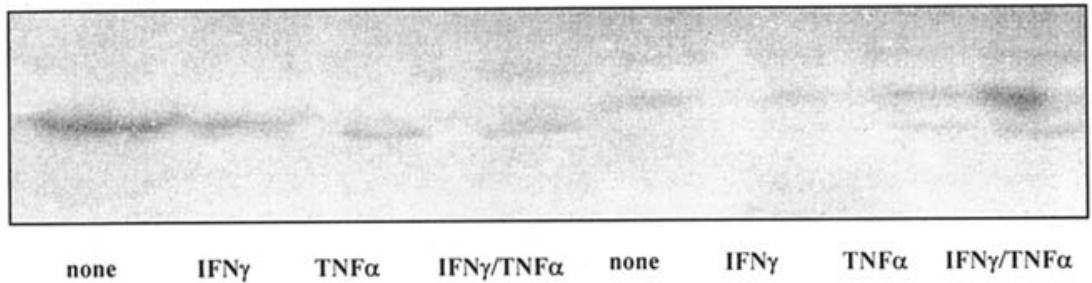

Media conditioned by tumor cells

Cell bodies of tumor cells

Figure 3. Change in uPA/uPAR expression in F10-M3 murine melanoma cells stimulated with IFN $\gamma$ and/or TNF $\alpha$. RT-PCR analysis of total RNA for uPAR and uPA (A), Western blotting of uPAR (B), and casein zymogram of conditioned media and cell bodies (C) of tumor cells grown in the presence and absence of cytokines.

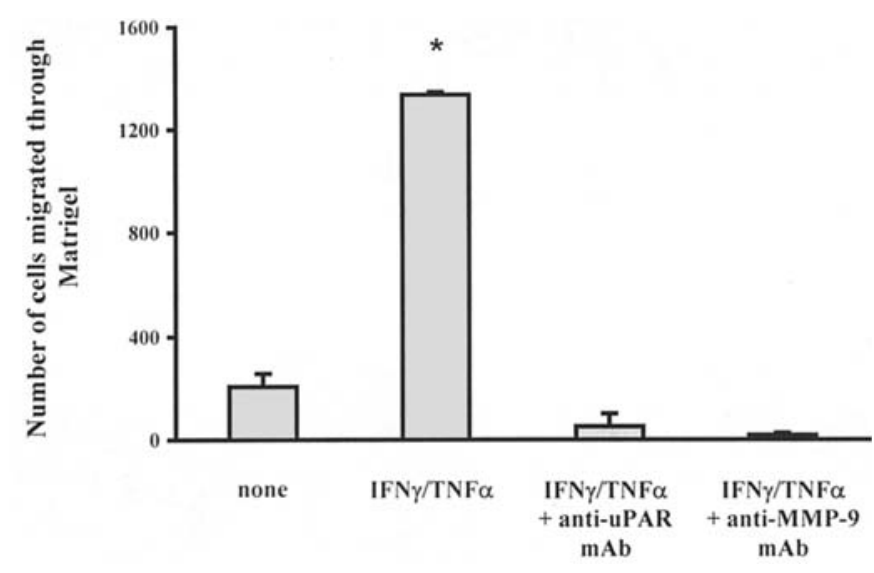

Figure 4. Invasiveness of F10-M3 murine melanoma cells costimulated with IFN $\gamma$ and TNF $\alpha$ and with IFN $\gamma$ and TNF $\alpha$ and anti-uPAR or anti-MMP-9 monoclonal antibodies (mAb). *Significantly different at $\mathrm{p}<0.001$.

Fig. 4 shows that both anti-uPAR and anti-MMP-9 monoclonal antibodies abrogated the enhanced invasiveness of melanoma cells costimulated with IFN $\gamma$ and TNF $\alpha$.

\section{Discussion}

An important feature of metastatic cells is their ability to escape from their site of origin by invading surrounding tissue, including basement membranes. The present study was aimed at clarifying whether IFN $\gamma / \mathrm{TNF} \alpha$-dependent invasive/metastatic phenotype in B16 murine melanoma cells was associated with an enhanced expression of UPA/UPAR and MMP protease activity. We found that the high lung-colonizing potential, as well as the better invasiveness through Matrigel-coated filters, expressed by murine melanoma cells costimulated with IFN $\gamma$ and TNF $\alpha$ was associated with an overexpression of UPA/uPAR and MMP protease activity. In particular, TNF $\alpha$ accounted for a higher expression of MMP-9 mRNA and pro-MMP-9 protein secretion, and the cooperation between IFN $\gamma$ and TNF $\alpha$ was responsible for a greater expression of uPAR mRNA and protein, leading to the enrichment of UPA on tumor cell membrane. It is possible that the cytokine-potentiation of invasiveness in B16 melanoma cells might be related to the activation of a program that implies an enhanced expression of uPAR, thereby favouring the partitioning of uPA on its receptor and initiation of a protease cascade which also includes proMMP-9 activation. The inhibition of the enhanced invasiveness of tumor cells costimulated with IFN $\gamma$ and TNF $\alpha$ by anti-uPAR and anti-MMP-9 monoclonal antibodies sustained the notion that the increased migration of melanoma cells was dependent on the cooperation between UPA/UPAR and MMP-9, and that there was not a hierarchy of a single system. In light of the co-expression by tumor cells of these two protease systems, Lakka et al (44) reported that a single vector capable of expressing small interfering RNA for UPAR and MMP-9 can block the expression of targeted proteases in glioblastoma cells, and consequently invasion, tumor growth and angiogenesis. Cooperation between UPA/UPAR and MMP-9 was found to be required for intravasation, a rate-limiting step for metastatic diffusion, of different types of cancer cells (epidermoid carcinoma cells, breast cancer cells, prostate cancer cells, fibrosarcoma cells) (45). Moreover, the evaluation of uPA/ UPAR and MMP-9 in pancreatic cancer cells led to the conclusion that these proteases are potential prognostic indicators, e.g. patients with overexpression of uPA and MMP-9 in their tumor cells have a trend toward a shorter survival time (46). MMP-9 is not the only member of the 
MMP system which has been shown to be functionally coupled with UPA/uPAR, as cooperation between the uPA system and MMP-2 was found by Ellenrieder et al (36) in the enhanced invasiveness of pancreatic cancer cells stimulated with TGF-B. Further clarification of the mechanisms by which uPA/uPAR and MMP-9 operate in tumor cells will be important, in view of evidence suggesting new functions for these proteases in cancer progression, e.g. adhesion, growth and apoptosis, angiogenesis and immune response (47-50).

In conclusion, the data reported in this study suggest that the striking invasive phenotype exhibited by B16 murine melanoma cells costimulated with IFN $\gamma$ and $\mathrm{TNF} \alpha$ was dependent on cooperation between the uPA/uPAR system and MMP-9 activity, a finding that might offer a novel therapeutic strategy to combat dissemination of tumor cells, e.g. targeting the extracellular mediators that work at the tumor-host communication interface.

\section{Acknowledgements}

This work was supported by grants from MURST $40 \%$ Cofin 2003 and 2004, Murst ex 60\% and Ente Cassa di Risparmio di Firenze.

\section{References}

1. Liotta LA and Khon EC: The microenvironment of the tumorhost interface. Nature 411: 375-379, 2001.

2. Fidler IJ: The organ microenvironment and cancer metastasis. Differentiation 70: 498-505, 2002.

3. Whitworth PW, Pak CC, Esgro J, Kleinerman ES and Fidler IJ: Macrophages and cancer. Cancer Metastasis Rev 8: 319-351, 1989/1990.

4. Fidler IJ and Schroit AJ: Recognition and destruction of neoplastic cells by activated macrophages: discrimination of altered self. Biochim Biophys Acta 948: 151-173, 1998

5. Kadhim SA and Rees RC: Enhancement of tumor growth in mice: evidence for the involvement of host macrophages. Cell Immunol 87: 259-269, 1984.

6. De Baetselier P, Kapon A, Katzav S, Tzehoval E, Dekegel D, Segal S and Feldman M: Selecting, accelerating and suppressing interactions between macrophages and tumor cells. Invasion Metastasis 5: 106-124, 1985.

7. Mashiba $\mathrm{H}$ and Matsunaga $\mathrm{K}$ : Inhibition and augmentation of lymphoma metastasis by adoptively transferred peritoneal macrophages in hamster. Cancer Lett 33: 11-18, 1986.

8. Mukai M, Shinkai K, Tateishi R, Mori Y and Akedo H: Macrophage potentiation of invasive capacity of rat ascites hepatoma cells. Cancer Res 47: 2167-2171, 1987.

9. Akedo H, Shinkai K, Mukai M and Komatsu K: Potentiation and inhibition of tumor cell invasion by host cells and mediators. Invasion Metastasis 9: 134-148, 1989.

10. Cecconi O, Calorini L, Mannini A, Mugnai G and Ruggieri S: Enhancement of lung-colonizing potential of murine tumor cell lines co-cultivated with activated macrophages. Clin Exp Metastasis 15: 94-101, 1997.

11. Pollard JW: Tumour-educated macrophages promote tumour progression and metastasis. Nat Rev Cancer 4: 71-78, 2004.

12. Sica A, Saccani A and Mantovani A: Tumor-associated macrophages: a molecular perspective. Int Immunopharmacol 2: 1045-1054, 2002

13. Mantovani A, Allavena P and Sica A: Tumour-associated macrophages as a prototypic type II polarised phagocyte population: role in tumour progression. Eur J Cancer 40: 1660-1667, 2004.

14. Lin EY, Nguyena AV, Russell RG and Pollard JW: Colonystimulating factor 1 promotes progression of mammary tumors to malignancy. J Exp Med 193: 727-740, 2001.

15. Calorini L, Mannini A, Bianchini F, Mugnai G and Ruggieri S: Biological properties associated with the enhanced lungcolonizing potential in a B16 murine melanoma line grown in a medium conditioned by syngeneic Corynebacterium parvumelicited macrophages. Clin Exp Metastasis 17: 889-895, 1999.
16. Calorini L, Bianchini F, Mannini A, Mugnai G and Ruggieri S: IFN gamma and TNF alpha account for a pro-clonogenic activity secreted by activated murine peritoneal macrophages. Clin Exp Metastasis 19: 259-264, 2002.

17. Taniguchi K, Karre K and Klein G: Lung colonization and metastasis by disseminated B16 melanoma cells: H-2 associated control at the level of the host and the tumor cells. Int J Cancer 36: 503-510, 1985 .

18. Kawano Y-I, Taniguchi K, Toshitani A and Nomoto K: Synergistic defense system by cooperative natural effectors against metastasis of B16 melanoma cells in $\mathrm{H}-2$-associated control: different behaviour of $\mathrm{H}-2^{+}$and $\mathrm{H}-2^{-}$cells in metastatic process. J Immunol 136: 4729-4734, 1986.

19. Lollini PL, de Giovanni C, del Re B, Nicoletti G, Contadini A, Tazzari PL, Landuzzi L, Scotlandi K and Nanni P: Enhancement of experimental metastatic ability by tumor necrosis factoralpha alone or in combination with interferon-gamma. Clin Exp Metastasis 8: 215-224, 1990.

20. Beatty GL and Paterson Y: IFN $\gamma$ can promote tumor evasion of the immune system in vivo by down-regulating cellular levels of an endogenous tumor antigen. J Immunol 165: 5502-5508, 2000.

21. Morel S, Levy F, Burlet-Schiltz O Brassuer F, Probst-Kepper M, Pietrquin AL, Monsarrat B, van Veltghoven R, Cerottini JC, Boon T, Gairin JE and van den Eynde BJ: Processing of some antigens by the standard proteasome but not by the immunoproteasome results in poor presentation by dendritic cells. Immunity 12: 107-117, 2000.

22. Mortarini R, Belli F, Parmiani G and Anichini A: Cytokinemediated modulation of HLA-class II, ICAM-1, LFA-3 and tumor-associated antigen profile of melanoma cells. Comparison with anti-proliferative activity by rIL1-beta, rTNF-alpha, rIFNgamma, rIL4 and their combinations. Int J Cancer 45: 334-341, 1990.

23. Zhu N, Lalla R, Eves P, Brown TL, King A, Kemp EH, Haycock JW and MacNeil S: Melanoma cell migration is upregulated by tumour necrosis factor-alpha and suppressed by alpha-melanocyte-stimulating hormone. Br J Cancer 90: 1457-1463, 2004.

24. Katerinaki E, Evans GS, Lorigan PC and MacNeil S: TNF-alpha increases human melanoma cell invasion and migration in vitro: the role of proteolytic enzymes. Br J Cancer 89: 1123-1129, 2003.

25. De Vries TJ, Quax PH, Denijn M, Verrijp KN, Verheijen JH, Verspaget HW, Weidle UH, Ruiter DJ and van Muijen GN: Plasminogen activators, their inhibitors, and urokinase receptor emerge in late stages of melanocytic tumor progression. Am J Pathol 144: 70-81, 1994.

26. Hofmann UB, Westphal JR, van Muijen GN and Ruiter DJ: Matrix metalloproteinases in human melanoma. J Invest Dermatol 115: 337-344, 2000.

27. Hofmann UB, Westphal JR, Waas ET, Zendman AJ, Cornelissen IM, Ruiter DJ and van Muijen GN: Matrix metalloproteinases in human melanoma cell lines and xenografts: increased expression of activated matrix metalloproteinase-2 (MMP-2) correlates with melanoma progression. Br J Cancer 81: 774-782, 1999.

28. D'Alessio S, Margheri F, Pucci M, del Rosso A, Monia BP, Bologna M, Leonetti C, Scarsella M, Zupi G, Fibbi G and del Rosso M: Antisense oligodeoxynucleotides for urokinaseplasminogen activator receptor have anti-invasive and antiproliferative effects in vitro and inhibit spontaneous metastases of human melanoma in mice. Int J Cancer 110: 125-133, 2004.

29. Itoh T, Tanioka M, Matsuda H, Nishimoto H, Yoshioka T, Suzuki R and Uehira M: Experimental metastasis is suppressed in MMP-9-deficient mice. Clin Exp Metastasis 17: 177-181, 1999.

30. Bjorklund M, Heikkila P and Koivunen E: Peptide inhibition of catalytic and noncatalytic activities of matrix metalloproteinase-9 blocks tumor cell migration and invasion. J Biol Chem 279: 29589-29597, 2004.

31. Schirren CG, Majewski S, Hunzelmann N, Heckmann M and Krieg T: The effect of interferon-gamma on the invasiveness of HT-1080 cells. Br J Dermatol 126: 331-336, 1992.

32. Sato H and Seiki M: Regulatory mechanism of $92 \mathrm{kDa}$ type IV collagenase gene expression which is associated with invasiveness of tumor cells. Oncogene 8: 395-405, 1993.

33. Hujanen ES, Vaisanen A, Zheng A, Tryggvason K and Turpeenniemi-Hujanen T: Modulation of Mr 72000 and 92000 type-IV collagenase (gelatinase A and B) gene expression by interferons alpha and gamma in human melanoma. Int J Cancer 58: 582-586, 1994. 
34. Tran-Thang C, Kruithof E, Lahm H, Schuster WA, Tada M and Sordat B: Modulation of the plasminogen activation system by inflammatory cytokines in human colon carcinoma cells. Br J Cancer 74: 846-852, 1996.

35. Qin H, Moellinger JD, Wells A, Windsor LJ, Sun Y and Benveniste EN: Transcriptional suppression of matrix metalloproteinase-2 gene expression in human astroglioma cells by TNF-alpha and IFN-gamma. J Immunol 161: 6664-6673, 1998.

36. Ellenrieder V, Hendler SF, Ruhland C, Boeck W, Adler G and Gress TM: TGF-beta-induced invasiveness of pancreatic cancer cells is mediated by matrix metalloproteinase- 2 and the urokinase plasminogen activator system. Int J Cancer 93: 204-211, 2001.

37. Slaton JW, Karashima T, Perrotte P, Inoue K, Kim SJ, Izawa J, Kedar D, McConkey DJ, Millikan R, Sweeney P, Yoshikawa C, Shuin T and Dinney CP: Treatment with low-dose interferonalpha restores the balance between matrix metalloproteinase-9 and E-cadherin expression in human transitional cell carcinoma of the bladder. Clin Cancer Res 7: 2840-2853, 2001.

38. Sanceau J, Boyd DD, Seiki M and Bauvois B: Interferons inhibit tumor necrosis factor-alpha-mediated matrix metalloproteinase-9 activation via interferon regulatory factor- 1 binding competition with NF-kappa B. J Biol Chem 277: 35766-35775, 2002.

39. Gattoni-Celli S, Calorini L, Simile MM and Ferrone S: Modulation by MHC class I antigens of the biology of melanoma cells. Non-immunological mechanism. Melanoma Res 3: 285-289, 1993.

40. Chen TR: In situ detection of mycoplasma contamination in cell cultures by fluorescent Hoechst 33258 stain. Exp Cell Res 104: 255-262, 1997.

41. Rakic JM, Lambert V, Munant C, Bajou K, Peyrollier K, Alvarez-Gonzalez ML, Carmeliet P, Foidart JM and Noel A: Mice without uPA, tPA, or plasminogen genes are resistant to experimental choroidal neovascularization. Invest Ophthalmol Vis Sci 44: 1732-1739, 2003.
42. Gutierrez LS, Schulman A, Brito-Robinson T, Noria F, Ploplis VA and Castellino FJ: Tumor development is retarded in mice lacking the gene for urokinase-type plasminogen activator or its inhibitor, plasminogen activator inhibitor-1. Cancer Res 60: 5839-5847, 2000.

43. Orlic D, Anderson S, Biesecker LG, Sorrentino BP and Bodine DM: Pluripotent hematopoietic stem cells contain high levels of mRNA for c-kit, GATA-2, p45 NF-E2, and c-myb and low levels or no mRNA for c-fms and the receptors for granulocyte colony-stimulating factor and interleukins 5 and 7. Proc Natl Acad Sci USA 92: 4601-4605, 1995.

44. Lakka SS, Gondi CS, Dinh DH, Olivero WC, Gujrati M, Rao VH, Sioka C and Rao JS: Specific interference of urokinase-type plasminogen activator receptor and matrix metalloproteinase-9 gene expression induced by double-stranded RNA results in decreased invasion, tumor growth, and angiogenesis in gliomas. J Biol Chem 280: 21882-21892, 2005.

45. Kim J, Yu W, Kovalski K and Ossowski L: Requirement for specific proteases in cancer cell intravasation as revealed by a novel semiquantitative PCR-based assay. Cell 94: 353-362, 1998.

46. Harvey SR, Hurd TC, Markus G, Martinick MI, Penetrante RM, Tan D, Venkaraman P, DeSouza N, Sait SN, Driscoll DL and Gibbs JF: Evaluation of urinary plasminogen activator, its receptor, matrix metalloproteinase-9, and von Willebrand factor in pancreatic cancer. Clin Cancer Res 9: 4935-4943, 2003.

47. Del Rosso M, Fibbi G, Pucci M, D'Alessio S, del Rosso A, Magnelli L and Chiarugi V: Multiple pathways of cell invasion are regulated by multiple families of serine proteases. Clin Exp Metastasis 193: 193-207, 2002.

48. Mignatti P and Rifkin DB: Non-enzimatic interactions between proteinases and the cell surface: novel roles in normal and malignant cell physiology. Adv Cancer Res 78: 103-157, 2000.

49. Chambers AF and Matrisian LM: Changing views of the role of matrix metalloproteinases in metastasis. J Natl Cancer Inst 89: 1260-1270, 1997.

50. Egeblad M and Werb Z: New functions for the matrix metalloproteinases in cancer progression. Nat Rev Cancer 2: 161-174, 2002 . 